ECONOMICS

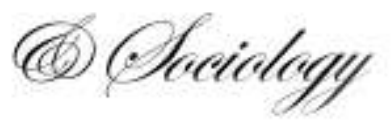

Paiva, I., \& Carvalho, L. (2018). Accounting and Management Practices in the Third Sector in Angola. Economics and Sociology, 11(3), 28-42. doi:10.14254/2071789X.2018/11-3/2

\author{
Inna Paiva, \\ Instituto Universitário de Lisboa \\ (ISCTE-IUL), Portugal, \\ E-mail:Inna_Paiva@iscte-iul.pt \\ ORCID: 0000-0002-9980-7503 \\ Luísa Carvalho, \\ CEFAGE-Universidade de \\ Évora and College of Business \\ Administration, Institute \\ Polytecnhic of Setúbal, Portugal \\ E-mail: \\ luisa.c.carvalho@esce.ips.pt \\ ORCID: 0000-0002-9804-7813 \\ Received: March, 2018 \\ 1st Revision: May, 2018 \\ Accepted: July, 2018 \\ DOI: $10.14254 / 2071-$ \\ 789X.2018/11-3/2 \\ JEL Classification: L31; \\ M00; M40.
}

\section{ACCOUNTING AND MANAGEMENT PRACTICES IN THE THIRD SECTOR IN ANGOLA} THE THIRD SECTOR IN ANGOLA

\begin{abstract}
This study seeks to analyse the relationship between accounting and management practices in organisations of the third sector in a less developed country, taking regional differences into account. Primary data were collected using a survey conducted among the third sector organisations in the provinces of Huíla, Benguela, Huambo and Namibe. The results of the study identify a relationship between the type of organisation and the origin of the resources obtained, the disclosure of financial statements, the use of operational plans and the use of budgets. This exploratory study contributes to the research on accounting and management in the third sector in that it is pioneering in the analysis of simultaneous influence of accounting and management characteristics in the four studied regions of Angola.
\end{abstract}

Keywords: Angola, accounting, management practices, third sector, economic development.

\title{
Introduction
}

Great and rapid changes that societies have undergone both economically, socially and politically, as well as culturally, have affected individuals and organizations inside them. One of the consequences of these economic transformations has been the expansion of the informal sector of the economy and, in turn, the activities of the third sector. In recent years, empirical studies have been focusing on the importance of the third sector activities along with their accounting and management practices (Lee, 2004; McCarthy, 2007; O'Dwyer \& Unerman, 2010; Sinclair \& Bolt, 2013). New perspectives have also been enhanced in the third sector so that its organizations have become more capable to cope with changes and challenges related to improving accounting and management practices (Parker, 2007; Taylor \& Taylor, 2014).

Independently of their prevalence and significance in industrialized and developed countries, third-sector organizations have also gained popularity and relevance in less developed economies (Salamon et al.,1999; Smillie \& Hailey, 2001). It has only been since the middle of 1980s that the conflict began moving towards eventual settlement, with the 
prospects for peace often seeming to depend largely on the attitudes of Cuba, South Africa, the Soviet Union and the United States. In this regard, Angola has been a special case in terms of macroeconomic stabilization and economic growth in the last decade.

Broadening economic growth is a major challenge for this country at the moment. Regional asymmetries are prevailing and are causing indecent and immoral social stratification by relegating social considerations and difficult economic conditions of the population to the secondary and tertiary levels of importance (World Bank, 2010). It is fundamental to imagine and implement a system that will make Angola a country where regional dissimilarities are confined to comparative advantages of each province, cultural and historical differences and geographical accidents. Performance of organizations in the third sector is a fundamental factor for continuous development of the regions in Angola (Doerfel et al., 2017).

Relevance of the information contained in financial statements is an essential tool for promoting capital market growth, facilitating access to finance for local businesses and promoting better business climate for the integration of local enterprises into the economy (Parker, 2007). Users of financial information are interested in knowing how and in which projects specifically the resources they have provided to organizations are applied. Preparation of financial statements is necessary to maintain the confidence that resources assigned to organizations are being used in a transparent way, covering the activities that contribute to the well-being of society (Cooney, 2006; Samkin \& Schneider, 2010).

The question of the relationship between accounting and management practices in the third-sector organizations in Angola is particularly important due to the lack of recent studies and given the significant consequences of regional differences, as well as overall economic growth in the country. Our main research question is therefore as follows: Is there a relationship between accounting and management practices of the third-sector organizations in Angola, taking regional differences into account? Our study addresses different third-sector organizations and regional development, both being the subjects of the increasing interest expressed by practitioners and scholars in the related fields.

For the purposes of this study, primary data were collected through interviews conducted between 2015 and 2016. The data were obtained on 63 third-sector organizations in Angola. The study establishes a relationship between the type of organization and different accounting and management practices, based on the socio-territorial contexts of the four provinces of Angola.

The results of this study identify a significant relationship between the type of organization and the use of accounting budgets, the use of operational plans, preparation of financial statements and the type of funding obtained. In addition, the results show that most organizations recognize the importance of accounting practices for their transactions, as well as the importance of financial information disclosure to stakeholders. This study has an exploratory and pioneering character, since investigations applied in the regional context of African countries are scarce.

This study makes several contributions to literature. First, it contributes to better understanding of the relationship between accounting and management practices in the third sector, taking regional differences in Angola context into account. Little is known about accounting and management practices in the context of less developed countries of the African continent because most of empirical evidence is South African in origin (Meyer \& Neethling, 2017). Secondly, we contribute to the economic development literature by paying special attention to identification of regional differences in the country. Finally, we also shed some light on the relationship between accounting and management practices and the types of third-sector organizations. 
This study also has practical implications. It can be useful for governments, especially for the development of policies and programmes to promote the elimination of regional disparities, partner networks and cooperation of regional government with the intervention of third-sector organizations in the regional economy.

The article is composed of the following parts. After a brief introduction, the first part presents the concept of the third sector as such, the typologies and the profile of the third sector in Angola, as well as its relationship with accounting and management practices. In the second part the methodological questions are discussed. In the third part, the results are presented. The last part of the study presents the conclusions and the perspectives for future research.

\section{Review of scientific literature}

\subsection{Importance of the third sector}

The study of nonprofit, third sector, or voluntary organizations is a quite new development in the history of the social sciences (Anheier, 2014). A significant proportion of the world economy exists to provide goods and services to society and to serve their members and not to obtain a return on investment like traditional mainstream companies. Research shows that the non-profit sector performs important social, economic and political functions in society (Gray, Bebbington \& Collison, 2006; O'Dwyer \& Unerman, 2008, 2010; Alcock, 2010; Unerman \& O'Dwyer, 2010). The non-profit sector is the sum of private, voluntary, non-profit organizations and associations (Anheier, 2014).

Apart from being prevalent and significant in industrialized and developed countries, third sector organizations have also gained popularity in less developed economies, including Africa, Asia and other areas and in terms of the limits on the action of local government, they can contribute to sustainable development in long term (Suditri et al., 2014). They have become major providers of goods and services (Smillie \& Hailey, 2001; Lewis, 2004; Gray et al., 2006; Unerman \& O’Dwyer, 2010). Salamon et al. (1999) also studied the non-profit sector in five developing countries and their findings revealed that at the time of their study, there were nearly 20,000 non-profit organizations in Egypt, close to 200,000 in Brazil and over 15,000 registered organizations in Thailand.

The third sector (or Social Economy also called no-profit organizations) includes cooperatives, mutual societies, non-profit associations, foundations and social enterprises. This study uses a broad definition of "third sector organization", which also includes "voluntary" or "non-profit" organizations, to indicate any self-governing bodies that are formally organized, independent from the state, non-profit-distributing, and benefit from some sort of voluntarism in their activities (Lindsay, Osborne and Bond, 2013).

Third sector organizations assume several features that differ according to the social, economic and political environment, and so they differ between countries and also reveal particular aspects when compared with other sectors (Salamon et al., 1999; Powell and Steinberg, 2006; Gariyo, 2013; Taylor and Taylor, 2014). According to Salamon et al. (1999), these organizations reveal five main characteristics: (i) Structured: follow formalities and roles; (ii) Private: although they receive public resources they are private and are not institutionally linked to the state; (iii) No distribution of profits: contrary to profit organizations, those of the third sector do not distribute profit. (iv) Autonomy: They have autonomy in their management; (v) Voluntary: in general these organizations reveal a high number of volunteers, i.e., unpaid labour.

They operate a very broad number of commercial activities, provide a wide range of products and services across the European single market and generate millions of jobs. 
Additionally, within the European Union and African, Caribbean and Pacific (ACP) countries, the parties agreed to conclude new trade agreements - Economic Partnership Agreements, progressively eliminating barriers to trade and by strengthening cooperation in related fields such as standardization, certification and quality control, competition policy, consumer policy and others.

\subsection{Accounting and management in the third sector}

Third sector organizations have emerged as key players in the delivery of public services to assist jobless people in improving their employability and moving from welfare to work (Lindsay, Osborne and Bond, 2013). Nevertheless, these organizations face several challenges, such as access to finance, low levels of recognition, varying regulatory environments and lack of entrepreneurial skills.

The lack of entrepreneurial skills is related to managerial skills and also accountability problems and difficulties in these kinds of organizations. The report of accountability reporting in the third sector is not a new discussion (Commission on Private Philanthropy and Public Needs, 1975; Edwards \& Hulme, 2013). Nowadays, the non-profit sector focuses on issues such as: measuring the value-added performance of non-profit organizations in terms of actual outcomes and impacts (Edwards \& Hulme, 2013); ensuring that trustees and other volunteers understand and fulfil their legal and professional responsibilities; public disclosure of operating practices related to fundraising and executive compensation; and fulfilling explicit or implicit obligations associated with public subsidies of non-profit activities (Bejar \& Oakley, 2013; Fowler, 2013; Karim 2013; Uphoff, 2013; Wils, 2013). Governance, accountability and transparency are nowadays-key issues for NPOs (Anheier, 2014).

However, the area of accountability in the third sector is understudied (Keating \& Frumkin, 2003; Kilby, 2006). While there are numerous specialized text-books on financial accountability in the third sector and other written materials dealing with specific issues of compliance, most general texts on non-profit management do not contain in-depth discussions on accountability from conceptual, managerial and policy-making standpoints (Keating and Frumkin, 2003; Kilby, 2006). In the same way, there is an obvious lack of rigorous research, particularly with respect to professionalism and accountability in the non-profit sector, although in recent years they have become more business-like (Maier, Meyer, \& Steinbereithner, 2014).

More research done on third sector working across borders in the developing world suggests that these organizations face more complexities and have greater accountability challenges. An interview with 152 leaders of transnational NGOs reveals that demands on accountability have increased in recent years (Schmitz, Raggo \& Vijfeijken, 2012). For 64\%, their view of accountability centres on financial management accountability and for $46 \%$, it centres on the mission of the organization and how they meet the expectations of the community. A sizeable proportion (38\%) describes accountability as transparency, whereas some primarily associate accountability with contractual and legal obligations.

Accountability sits high on the agenda for non-profit organizations, although they face more complexities in cross-border operations. Overall, the measurement of performance is linked to accounting and management practices, such as plans of activities, operations budgets, use of financial accounting and disclosure of financial information or drawing up management reports, although the key emphasis of the non-profit organization is on service delivery rather than profit distribution to owners.

These problems are gradually being overcome in non-profit organizations in the developed world. However, less developed countries, such as African countries, have 
remained in a stage of underdevelopment and underuse of important tools in these organizations.

\subsection{The third sector in Angola and the legal framework}

Third sector organizations are important in Angolan society, as in all societies, because they can play a central role in monitoring the preparation and implementation of fiscal policies and this can contribute to enhancing transparency, accountability and accountability efficiency in the management of public finances. In Angola, around $70 \%$ of the population lives on the poverty line and third-sector organizations end up playing a leading role in fighting poverty and intervening better in health, education, production, human rights and citizenship (AICEP, 2017).

Although it is directed towards the social aspect, the third sector clearly has an economic process that needs to and must be controlled and divulged to the users. Previous literature demonstrated that regional development is influenced by the way in which government develops and implements its policy on the creation conditions for business (Meyer \& Neethling, 2017; Habánik et al., 2016). The entities that are part of the third sector respond to general interest purposes that transcend the activity and the sale of products or services. The presentation of financial statements is necessary to maintain the confidence that public resources are being used honestly and in activities that contribute to the public good (Milbourne \& Cushman, 2012).

The main international and regional relations relevant to Angola's sustainable development are the African Development Bank (AfDB), Organization of the Petroleum Exporting Countries (OPEC), the United Nations (UN) and most of its specialized agencies (Funds, Programs, Specialized Agencies and Others UN Entities). The World Trade Organization has been involved since 23 November 1996. At a regional level it is part of the Southern African Development Community, although it has not yet joined its Free Trade Area.

In order to promote trust among all stakeholders, transparency should not only serve to inform, but should be part of the good practice of the organization, recognizing that good internal and external communication requires a commitment from the whole organization. This practice should not be confined to mandatory financial information alone, but account should also be taken of voluntary information of a different nature that could reduce the existing asymmetries between various users of financial information.

There is currently no active stock exchange in Angola. The regulatory body is the National Bank of Angola and the financial sector institutions is the first in Angola to present its financial statements in accordance with International Financial Reporting Standards as of January 1, 2017. All other companies must prepare their financial statements in conformity with the Angolan Accounting Law and the General Accounting Plan (PGC) that was adopted by Presidential Decree 82/01 of 16 November 2001.

This General Accounting Plan determines the mandatory financial statements for third-party entities and indicates the recognition, accounting records, financial statements and disclosure. Thus, a complete set of financial statements to be presented to the user is composed of the Balance sheet, Demonstration of results (by nature or by functions), Cash flow statement, and Notes.

The financial statements may also include supplemental charts and information based on or derived from demonstrations, which are expected to be read in conjunction therewith. The maps and supplementary information may deal, for example, with financial information of industrial and geographic segments and disclosures about the effects of price changes. In addition, financial statements in Angola do not include elements prepared by the management 
body, such as reports, exhibitions, discussion and analysis and similar elements that may be included in an annual financial report.

The objective of financial statements is to provide information about the financial position, performance and changes in the financial position of an entity. According to the PGC, the main purpose of the financial statements is to inform investors, employees, financiers, suppliers, customers, the Government and its departments and the general public of certain information that will allow them to make important decisions. The financial statements prepared for this purpose meet the needs of users and influence the decisionmaking process. Thus, the financial statements provide differentiated information depending on the interest of each user. Parker (2007) emphasizes that, since financial statements are the preferred way of informing stakeholders about the economic and financial position of economic entities, it is normal for them to be constantly concerned about how they should be prepared.

This theoretical framework aimed to have the necessary scope to cross different perspectives and concerns and we believe that it would be important to widen this dialogue in order to establish a link between issues of accounting and management practices and regional economic development in third sector entities in Angola.

\section{Methodological approach}

\subsection{Conceptual development}

This study aims to analyse the accounting and management practices of third sector organizations in Angola, attending to regional differences. In order to achieve this objective, we developed a framework based on a qualitative research method grounded in interviews (Beck and Manuel, 2008). The advantage of this method is that being face to face enables us to see facial expressions and body language. These can be jotted down as notes as the interview progresses and may be useful in the data analysis portion of the research.

The present study has an exploratory character, since the studies on this subject applied to Angola are scarce or practically non-existent.

Attending to the huge dimension of Angola and to the universe of third sector organizations in Angola, this research collected information from associations, Catholic organizations and non-profit organizations in the provinces of Huíla, Benguela, Huambo and Namibe. The selection of these regions was based on the scarcity of studies in this field applied to this geographic territory.

The study was conducted between December 2015 and March 2016. All participants received a self-addressed envelope, the survey instrument and a cover letter explaining the purpose of the study. We requested access from the senior administration for the initial mailing and telephony contact. We contacted 75 institutions; however we only collected data from 63. The final sample was 63 interviews (31 in Huíla, 20 in Benguela, 15 in Huambo, and 10 in Namibe), which were used for the final analysis.

\subsection{Sample}

A variety of social, economic and legal factors originating inside the country have influenced regional development (Meyer \& Neethling, 2017). It is since 2002, and after 27 years of civil war that devastated the country, that Angola has, of course, been taking the role of a regional power in the context of Sub-Saharan Africa, converging to a market economy, with a Product Gross Domestic Product (GDP) per capita which in 2015 and in terms of purchasing power parity, reached $\$ 7255$, substantially higher than in countries like Kenya 
and Nigeria. The country is rich in natural resources, with an emphasis on oil, which accounts for about $38 \%$ of GDP in 2016 and about $92 \%$ of exports. Subsistence agriculture, however, remains the main resource for the majority of the population, occupying about $45 \%$ of the labour force, although it only accounts for less than 11\% of total GDP. On the other hand, industry and services, which have a GDP weight of respectively $51.6 \%$ and $37.5 \%$, employ $55 \%$ of the total force of labour market (AICEP, 2017). We consider it relevant to present a brief characterization of these Angola provinces (Instituto Nacional de Estatística de Angola, 2015).

Huíla is a province with an area of $79,023 \mathrm{~km} 2$, located in the southwest of the country. The province has 14 municipalities and approximately 2,354,398 inhabitants, which represents approximately $10 \%$ of the national total. It is the second most populous province in Angola after Luanda. Of this population, $67.9 \%$ of the inhabitants aged over 15 were literate. In terms of housing, an overwhelming majority (97.5\%) of the population lived in dwellings with materials inappropriate for housing. In terms of sanitation, only $46 \%$ of the population used appropriate sanitation and only $31.7 \%$ of the population had access to electricity.

Benguela is a province of central and western Angola with an area of $39,827 \mathrm{~km} 2$, located 692 kilometres from the national capital, Luanda. The province has 10 municipalities and a population of 2,036,662 people, which represents approximately $8 \%$ of the national total, and is the third most populous province of Angola. Of this population, $60.5 \%$ of people over 15 were literate. In terms of housing, $79.1 \%$ of the population lived in dwellings with materials inappropriate for housing. $46 \%$ of the population had access to drinking water; in terms of sanitation, only $34.8 \%$ of the population used adequate sanitation and a very small percentage of only $29.4 \%$ had access to electricity.

Huambo is a province with an area of $34,270 \mathrm{~km} 2$ and is one of the geographically smaller provinces of Angola, situated in the central region of the country. The province has 11 municipalities and, with a population of $1,896,147$ people, has approximately $8 \%$ of the national total. Only $60.5 \%$ of the population over 15 years old was literate. In terms of housing, almost all $(97.6 \%)$ of the population lived in dwellings with materials inappropriate for housing. $38.6 \%$ of the population had access to drinking water; in terms of sanitation, $79 \%$ of the population used adequate sanitation, but only $14.5 \%$ had access to electricity.

Namibe is a province with an area of $57,091 \mathrm{~km} 2$, located on the south coast of Angola. The province has 5 municipalities and a population of 471,613 people, which represents approximately $1.9 \%$ of the national total. Only $53.6 \%$ of the population aged over 15 was literate. In terms of housing, just as in the other provinces, the vast majority $(87.8 \%)$ of the population lived in dwellings with inappropriate housing materials. According to the data, only $43.5 \%$ of the population had access to drinking water, and in terms of sanitation a small percentage $(26.7 \%)$ of the population used appropriate sanitation and only $32.1 \%$ had access to electricity from the network. According to the information presented, the provinces differ according to their physical dimension, and Huila is a province that shows a greater development of schooling and places of residence compared to others. The province of Namibe is smaller and demonstrates a lower level of development than the others.

\subsection{Empirical study}

We construct the interviews of 20 items, which was still inclusive of all the dimensions we wanted to test. The first part of questions includes the general questions (i.e., Type of organization, Activities, Year of organization, Origin of resources obtained for activity, Yearly budget, Year operating costs, Year of respondent, Gender of respondent, Position of respondent, Experience of working, Degree, Length of stay in the entity). The second part of questions includes the accounting and management practice questions (i.e. Use 
of operational planning, Use of annual budgets, Use of organized accounting, Preparation and disclosure of financial statements, Preparation of management report).

In our study, the accounting and management practice variables were measured using a six-point Likert scale: "completely false" (0), "mostly false" (1), "somewhat false" (2), "somewhat true" (3), "mostly true" (4), or "completely true" (5). A positive value shows the presence of an accounting and management practices in entities and a low value suggests the absence of such practices.

Our results demonstrated the following respondent characteristics that were homogeneous for the four regions of Angola. The respondents were almost all either small groups or large organizations. For most of them, fluctuation in membership over a one-year period was negligible and these organizations also maintained a corresponding stability in the number of service users in the same period. Most had budgets of more than 250 thousand dollars a year, and nearly half of these declared operating costs of over a 100 thousand dollars per year. The majority (84.1\%) were formed after 1980 and $21.1 \%$ were less than five years old.

The data collected were statistically treated through data analysis techniques of descriptive and inferential statistics.

\section{Results and discussion}

This section presents the main results of the data collected. Table 1 characterizes the organizational data by province, namely the type of organization, activity carried out and experience of the organization. Panel A presents the results disaggregated by type of organization, Panel B presents the results by type of activity carried out and Panel C presents the results by experience of the organization.

Table 1, Panel A presents the descriptive statistics of the distribution of organizations by type in the four provinces selected for the study. The results show that most of the organizations surveyed are associations $(44.0 \%)$, followed by NGOs (21\%), PISS (Mercy) $(14 \%)$, others $(10 \%)$, cooperatives $(6 \%)$, and finally the foundations (6\%). Most of the associations and foundations are located in the Huíla and Benguela provinces, while the NGOs are distributed in Huíla, Benguela and Namibe.

Panel B of Table 1 presents the data by the type of activity. The data show that, in general, $30 \%$ are from the culture and recreation area, $25 \%$ from social assistance, $16 \%$ from health and wellness, $8 \%$ from education and research, and $8 \%$ from other activities. The group of other activities incorporates human rights, religious assistance and other nonclassified activities. The activity of culture and recreation, health and wellness, education and research is predominant in Huíla, while the social assistance activity dominates the Benguela province.

The years of existence of an organization is revealed by its experience. Panel $\mathrm{C}$ of Table 1 represents the results obtained at 5-year intervals. Most of the organizations surveyed are relatively new and have worked for less than 5 years (33.3\%), those with between 11 and 20 years of age represent $28 \%$, organizations that have operated for more than 20 years represent $21 \%$ of the respondents, and, finally, $18.7 \%$ are organizations that have been operating between 6 and 10 years. Organizations under the age of 5 predominate in Huíla, while organizations over the age of 20 are distributed throughout the provinces. 
Table 1. Organizational data disaggregated by province

Huíla Benguela $\quad$ Huambo $\quad$ Namibe $\quad$ Total, $\mathrm{N}$ Total, $\%$

Panel A: Data by type of organization

\begin{tabular}{lllllll}
\hline Non-profit associations & 11 & 10 & 5 & 2 & 28 & 44 \\
\hline Cooperative - PISS & 3 & 1 & 0 & 0 & 4 & 6 \\
\hline Foundation - Assoc. & 2 & 1 & 0 & 0 & 3 & 5 \\
\hline PISS (Mercy) & 2 & 3 & 3 & 1 & 9 & 14 \\
\hline ONG - PISS & 6 & 3 & 1 & 3 & 13 & 21 \\
\hline Other - PISS & 1 & 0 & 3 & 2 & 6 & 10 \\
\hline Total & 25 & 18 & 12 & 8 & 63 & 100 \\
\hline
\end{tabular}

Panel B: Data by type of activities developed

\begin{tabular}{lllllll}
\hline Culture and recreation & 9 & 7 & 2 & 1 & 19 & 30 \\
\hline Social assistance & 4 & 6 & 4 & 2 & 16 & 25 \\
\hline Health and wellness & 4 & 2 & 2 & 2 & 10 & 16 \\
\hline Education and research & 2 & 1 & 1 & 1 & 5 & 8 \\
\hline Trade and services & 1 & 0 & 1 & 1 & 3 & 5 \\
\hline Financial activities & 2 & 0 & 1 & 0 & 3 & 5 \\
$\begin{array}{l}\text { Professional and trade union } \\
\text { organizations }\end{array}$ & 1 & 1 & 0 & 0 & 2 & 3 \\
\hline Other & 2 & 1 & 1 & 1 & 5 & 8 \\
\hline Total & 25 & 18 & 12 & 8 & 63 & 100 \\
\hline
\end{tabular}

Panel C: Experience of organization

\begin{tabular}{lllllll}
\hline$<5$ years & 8 & 5 & 5 & 3 & 21 & 33 \\
\hline $6-10$ years & 8 & 3 & 0 & 0 & 11 & 18 \\
\hline $11-20$ years & 5 & 6 & 5 & 2 & 18 & 28 \\
\hline$>20$ years & 4 & 4 & 2 & 3 & 13 & 21 \\
\hline Total & 25 & 18 & 12 & 8 & 63 & 100 \\
\hline
\end{tabular}

\section{Source: own compilation}

This exploratory study aims to analyse the relationship of accounting and management practices in third sector organizations in Angola taking into account regional differences. For this purpose, the Pearson chi-square test was used to analyse the correlations between the type of organization and the use of accounting and management instruments, considering the study regions. Table 2 shows the results obtained by each region.

Regarding the relationship between the type of organization and the use of plans, the results obtained show in total, and for each province, a significant $10 \%$ relationship between the type of organization and the use of operational planning. The additional results show that the PISS (Mercy) are those that do least planning of the financial and institutional part when compared with the associations and with the NGOs (88.9\% vs $44.4 \%$ and $53.8 \%$ ). In fact, planning is about outlining the purpose of a given organization, outlining its strategies and identifying strengths and weaknesses. In general, the results indicate that the organizations in each province constitute their operational plans to carry out their specific activities to solve social problems.

Regarding the relationship between the type of the organization and the use of budgets, the results obtained show a positive and significant relationship at $10 \%$. For the regions, the results show a significant relationship at $10 \%$ for Huíla and Huambo and $5 \%$ for Benguela. The relationship indicates that the type of organization in general, and the Huíla, 
Huambo and Benguela regions depend on the use of budgets. Specifically, the results by type of organization show that associations are those that do most and use budgets for projects, compared to the rest of organizations $(33.3 \%$ vs. $12.5 \%$ and $0.0 \%)$.

Table 2. Results the Pearson test of means by regions

\begin{tabular}{|c|c|c|c|c|c|}
\hline Test of means & Huíla & Benguela & Huambo & Namibe & $\begin{array}{l}\text { Total } \\
\text { Pearson Qui- } \\
\text { square }\end{array}$ \\
\hline $\begin{array}{l}\text { Relationship between the type of } \\
\text { organization and the use of } \\
\text { operational planning }\end{array}$ & $0.082 *$ & $0.057^{*}$ & $0.073^{*}$ & $0.098^{*}$ & $0.069^{*}$ \\
\hline $\begin{array}{l}\text { Relationship between the type of } \\
\text { organization and the use of budgets }\end{array}$ & $0.072 *$ & $0.044 * *$ & $0.067 *$ & 0.103 & $0.076^{*}$ \\
\hline $\begin{array}{l}\text { Relationship between organization } \\
\text { type and organized accounting }\end{array}$ & $0.056^{*}$ & $0.083^{*}$ & 0.146 & 0.290 & $0.064 *$ \\
\hline $\begin{array}{l}\text { Relationship between the type of } \\
\text { organization and the preparation } \\
\text { and disclosure of financial } \\
\text { statements }\end{array}$ & $0.040 *$ & $0.076^{* *}$ & $0.094 *$ & 0.189 & $0.043 * *$ \\
\hline $\begin{array}{l}\text { Relationship between the type of } \\
\text { organization and preparation and } \\
\text { dissemination of management } \\
\text { report/activities }\end{array}$ & 0.011 & $0.067^{*}$ & 0.089 & 0.028 & 0.186 \\
\hline $\begin{array}{l}\text { Relationship between the type of } \\
\text { organization and the origin of } \\
\text { resources obtained for activity }\end{array}$ & $0.003^{* *}$ & $0.000 * * *$ & $0.046^{* *}$ & $0.002 *$ & $0.003 * *$ \\
\hline
\end{tabular}

Concerning the question of the type of organization and the organized accounts, the results obtained show a positive and significant relationship at $10 \%$. By regions, the results indicate a significant relationship at $10 \%$ for Huíla and Benguela. The results indicate that organized accounting predominates in general, and also in the Huila and Benguela regions, and in organizations as associations (88.9\%).

Regarding the question of the relationship between the type of organization and the preparation and disclosure of financial statements, the results show a positive and significant relationship at 5\%. By regions, the results indicate a significant relationship at $5 \%$ for Benguela and $10 \%$ for Huíla and Benguela. The results indicate that the preparation and disclosure of financial statements has the highest percentage in associations and NGOs ( $97.0 \%$ vs. $60.5 \%$ ) compared to the Misericordia. Presentation of accounts to the users of the financial information, in this case, mainly to the state, donors, collaborators and financiers, demonstrates the transparency of the organizations. The disclosure of financial statements is part of the response to those that help the maintenance and continuity of the entities.

Regarding the question of the relationship between the type of organization and the preparation and disclosure of management report/activities, the results obtained demonstrate that in total, there is no statistically significant relationship. However, the analysis by regions shows a significant relationship at $10 \%$ for Huíla and Benguela. By type of organization, the results indicate that the publication of management report/activities are higher in NGOs and lower in associations $(92.3 \%$ vs $74.1 \%)$. The results indicate that non-governmental organizations have a greater need to demonstrate the work done for society to their users. The 
information contained in the management report can be an important source of resources to assist in its maintenance and continuity.

Finally, the last question concerns the establishment of the relationship between the type of organization and the source of resources obtained. In the whole and also by regions, the results indicate a significant relation at $1 \%$ for Benguela, 5\% for Huíla and Huambo and $10 \%$ for Namibe. The results indicate that their own resources are more recurrent in the Misericordia and lower in the associations $(66.7 \%$ vs $48.1 \%)$. The results demonstrated that there is a significant relationship between the type of organization and origin of resources obtained in each region analysed.

This study discusses the accounting and management practices of third sector organizations in Angola, attending to regional differences. Data showed that there is a significant relationship between the type of organization and the use of operational plans, the use of accounting budgets, the preparation of financial statements and the type of funding obtained in most important regions of Angola. These results suggest that most organizations recognize the importance of accounting and perform bookkeeping of their transactions, as well as disclosing financial information to stakeholders.

The results suggested that the preparation and dissemination of the management report should be considerably improved. Only in more developed regions (Huíla and Benguela) is recognition given to the importance of information contained in the management report that can be used as the source to maintain the continuity of work for society. This is not surprising, given that fact that while the financial information presented by the entities is mandatory by law, the preparation of the management report is voluntary. This study argues that financial accountability sits high on the agenda for third sector organizations, although they face more complexities in cross-border operations (Doerfel et al., 2017). Financial viability is taken to be a measure of accountability of third sector organizations which are expanding from operational plans, accounting budgets, and management report.

Habánic et al. (2016) argued the importance of changes in legislation, competences and financial incentives for promoting research and development investments and innovations in industry, technologies and services, as well attracting capital for support R\&D and innovation. It is a fact that economic development is recognized as one of the dominant factors and is subject of intense academic research that explores linkages between the space, economic growth, innovation and competitiveness of a region. Our study argues that regional development in terms of ensuring sustainable growth and standards of living must be expanded to the social and economic potential of the region. Additionally, for Plachciak et al. (2015), reflection on the principle of sustainable development within the context of apparent consciousness plays a purposeful role for previous attempts at implementation as well as planning new ways of understanding the integrated order of social, economic and environmental spheres. Therefore, the idea of sustainable and continuous development plays an important role. The search for new and better solutions to the existing social order seems to be an indispensable challenge.

In an international context, it is important to note that we can find various realities; the management practices adopted by NPOs in developed and developing countries could reveal suitable differences based on the resources, legal issues, type of NPO (international versus national) and environmental context, geographical localization (in large cities or in rural area) etc., which could influence the adoption or not of professional rules to manage these organizations. Nevertheless, nowadays it is important to point out some conditions and challenges faced by these organizations that could influence their performance, such as technology (information technology: social media, e-government, e-commerce, etc.); population flows in the world - demographics, world migration flows, internal migrations from rural areas to large cities influence the dynamics of NPOs; negative environmental 
impacts and catastrophe that lack access to some resources (water, land, etc.) and limit traditional activities such as agriculture. The economic, social, political and organizational changes are aggravated by the interconnectedness of the world (Bryson, 2018).

\section{Conclusions}

The huge and rapid changes that societies have undergone economically, socially, politically and also culturally have affected individuals and organizations. In this context, third sector organizations play an increasingly relevant role by covering needs not covered by the state. This scenario assumes particular emphasis in the context of less developed countries, as Angola. In addition, the role played by these organizations requires them to have professional expertise in management and accounting regulations, thus giving credibility and ensuring the transparency of their performance.

Financial information users are interested in knowing how and in what projects the resources that they give to third sector organizations are applied. Thus, the preparation of the financial statements is necessary to maintain confidence that the resources allocated to these organizations are being well used, with transparency through the development of activities that contribute to the well-being of society. It is within this problematic context that this study fits, analysing the accounting practices in third sector organizations in Angola in a regional context.

Through the information collected from 63 third sector organizations from 4 provinces of Angola, the study establishes a relationship between the type of organization and the different accounting practices, based on socio-territorial contexts of these four Angolan provinces. Most of the organizations interviewed are associations, followed by NGOs, mostly in the areas of culture and social assistance. The activity of culture and recreation, health and wellness, education and research is predominant in Huíla, while, the social assistance activity dominates the Benguela province. These differences may be associated with different levels of regional development and indicate different regional needs depending on the territory of location. Most of the associations and foundations are located in the Huíla and Benguela provinces, while the NGOs are located in Huíla, Benguela and Namibe. The youth of these organizations should also be mentioned, the majority being relatively recent, that is, they have been working for less than 5 years (33.3\%), with those between 11 and 20 years of age representing $28 \%$. This may indicate the relationship between the weight of the informal economy and the recent reorganization of the country after the end of the civil war.

The results of the study identify a significant relationship between the type of organization and the use of accounting budgets, the use of operational plans, the preparation of financial statements and the type of funding obtained. In addition, the results demonstrate that most organizations recognize the importance of accounting, and perform bookkeeping of their transactions, as well as disclosing financial information to stakeholders. From the point of view of the regional differences between organizations of the four regions studied there are some relevant points to note.

This exploratory study presents some limitations, namely in terms of sample size and the possibility of generalizing the results. However, due to the lack of empirical studies applied to these regions, it may contribute to pointing out lines for future research, aiming to follow up on this research, extending the sample to other regions and expanding the number of organizations studied. 


\section{Acknowledgement}

This article was funded by the UID / ECO / 04007/2013 project (POCI-01-0145FEDER-007659).

\section{References}

AICEP. (2017). Angola Ficha de Mercado. Retrieved January 26, 2018, from http://portugalglobal.pt/PT/Biblioteca/Paginas/Detalhe.aspx?documentId=c394b4f8db0b-4d6a-b38c-95ed9a940b5d

Anheier, H. (2014). Non-Profit Organizations. Theory, Management. Policy. Second Edition, Routledge, London.

Beck, S. E., \& Manuel, K. (2008). Practical research methods for librarians and information professionals. New York, NY: Neal-Schuman.

Bryson, J. (2018). Strategic Planning. For Public and Non-Profit Organizations. Fifth edition, Wiley, New Jersey.

Commission on Private Philanthropy and Public Needs. (1975). Giving in America: Toward a Stronger Voluntary Sector. Washington, DC: Commission on Private Philanthropy and Public Needs.

Cooney, K. (2006). The institutional and technical structuring of non-profit ventures: Case study of a US hybrid organization caught between two fields. Voluntas: International Journal of Voluntary and Non-profit Organisations, 17, 143-161.

Decree-Law $\mathrm{n}^{\mathrm{o}}$ 82/01, November, 16. (2001). Approves the General Accounting Plan. Angola.

Doerfel, M.L., Autoba, Y., \& Harris, J.L. (2017). (Un)Obtrusive Control in Emergent Networks: Examining Funding Agencies' Control Over Nonprofit Networks. Nonprofit and Voluntary Sector Quarterly, 46(3), pp. 469-487.

Edwards, M. \& Hulme, D. (2013). NGO Performance and Accountability: Introduction and Overview. In Non-Governmental Organisations. Performance and Accountability. Beyond the Magic Bullet. Edited by Michael Edwards and David Hulme, Routledge, New York.

Fowler, A. (2013). Assessing NGO Performance. in Performance and Accountability. Beyond the Magic Bullet. Edited by Michael Edwards and David Hulme, Routledge, New York.

Gariyo, Z. (2013). NGOs in East Africa: A view from bellow. in Performance and Accountability. Beyond the Magic Bullet. Edited by Michael Edwards and David Hulme, Routledge, New York.

Gray, R., Bebbington, J., \& Collison, D. (2006). NGOs, civil society and accountability: Making the people accountable to capital. Accounting, Auditing and Accountability Journal, 19(3), 319-348.

Habánik, J., Kordoš, M., \& Hošták, P. (2016). Competitiveness of Slovak Economy and Regional Development Policies. Journal of International Studies, 9(1), 144-155.

Instituto Nacional de Estatística de Angola. (2015). Rretrieved February 3, 2018, from http://www.ine.gov.ao/xportal/xmain?xpid=ine

Karim, M. (2013). NGOs in Bangladesh: Issues of Legitimacy and Accountability. in NonGovernmental Organisations. In Performance and Accountability. Beyond the Magic Bullet. Edited by Michael Edwards and David Hulme, Routledge, New York.

Keating, E., \& Frumkin, P. (2003). Reengineering Nonprofit Financial Accountability: Toward a More Reliable Foundation for Regulation. Public Administration Review, 63 (1), 3-15. 
Kilby, P. (2006). Accountability for Empowerment: Dilemmas Facing Non-Governmental Organizations. World Development, 34(6), 951-963.

Lee, M. (2004). Public reporting: A neglected aspect of non-profit accountability. Non-profit Management and Leadership, 15(2), 169-185.

Lewis, D. (2004). On the difficulty of studying civil society: NGOs, state and democracy in Bangladesh. Contributions to Indian Sociology, 38(3), 299-322.

Lindsay, C., Osborne, S. \& Bond, S. (2013). The 'new public governance' and employability services in an era of crisis: challenges for third sector organizations in Scotland. Public Administration, 92(1), 192-207.

Maier, F., Meyer, M., \& Steinbereithner, M. (2014). Nonprofit Organizations Becoming Business-Like: A Systematic Review. Nonprofit and Voluntary Sector Quarterly, 45(1), 64-86.

McCarthy, J. (2007). The ingredients of financial transparency. Non-profit and Voluntary Sector Quarterly, 36(1), 156-164.

Meyer, D.F., \& Neethling, J.R. (2017). Measurement of the enabling development environment: a comparative study in a developing region. Economics and Sociology, 10(4), 67-82. doi:10.14254/2071-789X.2017/10-4/6

Milbourne, L. and Cushman, M. (2012). From the third sector to the big society: how changing UK Government policies have eroded third sector trust. Voluntas: International Journal of Voluntary and Non-profit Organisations, 4, 485-508.

O'Dwyer, B., and Unerman, J. (2008). The paradox of greater NGO accountability: A case study. Accounting, Organizations and Society, 33, 801-824.

O'Dwyer, B., and Unerman, J. (2010). Enhancing the role of accountability in promoting the rights of beneficiaries of development NGOs. Accounting and Business Research, 40(5), 451-471.

Parker, L.D. (2007). Financial and external reporting research: The broadening corporate governance challenge. Accounting and Business Research, 37(1), 39-54.

Plachciak, A., Zielinska, A., \& Bilan, Y. (2015). Sustainable development as an utopian paradigm. In Raišiene A.G. (eds.), Drivers for Progress in the Global Society Edition: The 3rd European Interdisciplinary Forum 2015, Bologna: MEDIMOND Publishing Company, pp.169-175.

Powell, W.W., \& Steinberg, R. (Eds.). (2006). The non-profit sector. Research handbook. New Haven and London: Yale University Press, $2^{\text {nd }}$ Edition.

Salamon, L. M., Anheier, H., List, R., Toepler, S., Sokolowski, S.W., \& Associates. (1999). Global Civil Society: Dimensions of the Nonprofit Sector. Baltimore: Center for Civil Society Studies, Institute for Policy Studies.

Samkin, G., \& Schneider, A. (2010). Accountability, narrative reporting and legitimation. Accounting, Auditing \& Accountability Journal, 23(2), 256-289.

Sinclair, R., \& Bolt, R. (2013). Third Sector Accounting Standard Setting: Do Third Sector Stakeholders Have Voice?. Voluntas: International Journal of Voluntary and Non-profit Organisations, 24, 760-784.

Schmitz, H. P., Raggo, P., \& Vijfeijken, T. B. (2012). Accountability of transnational NGOs: Aspirations vs. practice. Non-profit and Voluntary Sector Quarterly, 41, 1175-1194.

Smillie, I., \& Hailey, J. (2001). Managing for change: Leadership, strategy and management in Asian NGO. London: Earthscan.

Taylor, M., \& Taylor, A. (2014). Performance measurement in the Third Sector: the development of a stakeholder-focussed research agenda, Production Planning \& Control, 25(16), 1370-1385.

Unerman, J., \& O'Dwyer, B. (2010). NGO accountability and sustainability issues in the changing global environment. Public Management Review, 12(4), 475-486. 
Uphoff, N. (2013). Why NGOs are not Third sector? A sectoral analysis with some thoughts on accountability, sustainability an evaluation. In Performance and Accountability. Beyond the Magic Bullet. Edited by Michael Edwards and David Hulme, Routledge, New York.

Wils, F. (2013). Scaling-up Mainstreaming and Accountability: The challenge for NGOs. In Performance and Accountability. Beyond the Magic Bullet. Edited by Michael Edwards and David Hulme, Routledge, New York.

World Bank. (2010). Doing Business 2011: Making a Difference for Entrepreneurs - Angola, US. 